\title{
The Effectiveness of Andragogically Oriented Teaching Method to Improve the Male Students' Achievement of Teaching Practice
}

\author{
Rismiyanto $^{1}$, Mursid Saleh ${ }^{1}$, Januarius Mujiyanto ${ }^{1} \&$ Warsono $^{1}$ \\ ${ }^{1}$ Semarang State University, Indonesia \\ Correspondence: Rismiyanto, Semarang State University, Indonesia. Tel: 62-856-269-2494. E-mail: \\ ristyasila@yahoo.com; rismiyanto@umk.ac.id
}

Received: December 13, 2017

Accepted: January 16, 2018 Online Published: January 18, 2018

doi: 10.5539/elt.v11n2p113

URL: http://doi.org/10.5539/elt.v11n2p113

\begin{abstract}
Students at universities are still frequently found to have low independency in learning. Besides, lecturers also still have tendency to treat students as if they were young learners, or in other words, the lecturers still use pedagogically oriented teaching methods (POTM); although they claimed themselves to have applied methods of teaching orienting to the characteristics of adult learners or andragogically oriented teaching methods (AOTM). This also happens to the students at English Education Department of Muria Kudus University (EED MKU), and affects their achievement of language leaning, in particular theirs of teaching practice. Some schools in which the students conduct teaching internship consider that the students' achievement of teaching is still less satisfactory, and they tend to be less creative and less independent in preparing the teaching, particularly related to the use of instructional skills of teachnig, such the use of classroom language and the use of things neeeded in teaching as media of teaching. This is a quantitative study involving 87 students joining Speaking for Instructional Purposes (SIP) classes at EED MKU. The instruments used are pre and post tests of teaching practice in SIP classes.This study aims to compare the effectiveness of implementing AOTM and POTM to improve the female and the male students' achievement of teaching practice. The results reveal that AOTM is more effectively implemented to improve the male students than the female ones.
\end{abstract}

Keywords: andragogically oriented teaching methods, pedagogically oriented teaching method, male students, achievement of teaching practice

\section{Introduction}

It is necessary to select the appropriate method of teaching if satisfactory learning achievement wants to be obtained. There are some factors affecting the selection of teaching method. One of them is considering the age of the learners. Regarding the age, learners are categorized into young learners and adult learners; and the selection of teaching method should perceive whether the students belong to young or adult learners.

In the level of philosophy, there are two kinds of teaching methods. They are andragogy and pedagogy. Both of them are not directly teaching methods which can be implemented in the teaching and learning process; but they both contribute philosophical orientation to the kinds of teaching method in the technical or operational level. Andragogy is a philosophical teaching method orientation considered appropriate to be given to adult learners, while pedagogy is the one appropriate to be implemented to the young learners.

Students at universities, seen from their age, are certainly categorized into adult learners. Andragogy is therefore considered as the prompt teaching method orientation. However, the fact frequently found is that the students still have low independency of learning; and this is not the character of adult learners. In addition, the lecturers themselves still often practically treat the students as young learners, although they claimed to already design the syllabus and the lesson plan oriented to the teaching method for adult learners. This fact might be seen at EED MKU. Constructive criticisms come from some schools where the students of EED MKU conduct teaching practice; the students still have low achievement of teaching practice as they also still have low independency and creativity in preparing the teaching, particularly related to the use of instructional skills of teachnig, such the use of classroom language and the use of things neeeded in teaching as media of teaching. 
This study is trying to offer solution to cope with the problems as some previous researches revealed that andragogy had took good chances to effective teaching method orientations to improve the students' achievement particularly their of language learning.

Christian (1983) made an adaptation from Hadley's (1975) EOQ, for civilian-military students which attended classes at Tinker Air Force Base. He revealed differences dealing with if classes were mandatory or voluntary. He did not investigate possible relationships between educational orientation, age and gender.

Davenport and Davenport (1985) made a replication of Christian's (1983) study including the relationship between age, sex, academic achievement, and educational orientation among students at the University of Wyoming. Their study revealed that andragogical orientation was more appropriate for female students.

Choy and Delahaye (2002) in his investigation on the learning approaches, study orientation, and readiness for self-directed learning of 266 youth aged 17-24 years old and enrolled in four Technical and Further Education Institutes, showed that a predominant surface approach to learning, a preference for an andragogical orientation, and a low level of readiness for self-directed learning mostly happened to the youth.

Wilson (2005) in his research to produce a sound psychometric instrument provided insight of andragogy's effect on two student outcomes, learning and satisfaction. The findings indicated adult learners enrolled in a MBA degree program gave evidence of learning and were not affected by andragogy. However, satisfaction with instructor and course was influenced by perception of andragogical teaching behaviors.

Deveci (2007) initiated a research on andragogical and pedagogical orientations of adult learners learning English as a foreign language. The research aimed at revealing the andragogical and pedagogical orientations of Turkish adult EFL learners.

Finally, Sealana (2014) investigated and recorded the efficacy of andragogical instructional delivery methods in comparison to traditional (pedagogical) instructional delivery methods to improve teaching and training methodologies for learning government-mandated course content.

Referring to the various results of the previous researches on andragogy, this study is another similar research to compare the effectiveness of AOTM and POTM to improve the female and male students' achievement of teaching practice in SIP classes. SIP is one of the courses preparing students with teaching competency before they join Microteaching and Teaching Internship courses in the following semester. This course mostly demands the students to do practicing activities; such as preparing media of teaching, preparing instructional skills of teaching including classroom language, and classroom management.

\subsection{Andragogy}

Andragogy etimologically derives from a Greek root word, agogus meaning to lead. Andra means adult. Andragogy terminologically means "the art and science of teaching/leading adults" (Knowles, 1980). As a teaching method orientation, in andragogy the learner is the centre; while the teacher is mostly the facilitator. Again, in andragogy adult learners have an andragogical experience of self-direction, autonomy, responsibility for decisions, resource of experience, performance of social roles, and immediacy of application or action.

Knowles' recommendation (1980) is that andragogical orientation of teaching method accomplishes more meaningful outcomes because it motivates learners to freely choose the learning goals, content, and processes. Andragogical orientation has learners expect the teacher to give an environment that leads learning, give some control over the learning process, and support higher levels of self-direction (Henry, 2009).

\subsubsection{Andragogically Oriented Teaching Method (AOTM)}

Andragogy does not belong to teaching method, but tends to go to the level philosophical concepts representing the adult learners' involvement in teaching and learning process. The andragogical effects in teaching are seen through teaching methods. In other words, there are many teaching methods representing and orienting to andragogy or andragogically oriented. Those kinds of teaching methods are as presented as follows:

1) Small group discussion and peer instruction (also called "Think Pair-Share" or "Concept Tests").

Students is invited to think about the answer to a question the instructor gives, and discuss the question themselves. Some students are chosen to present the consensus to the class. (Anderson et al., 2005)

\section{2) Effective use of clickers}

Hand-held electronic devices isto make students anonymously choose answers of multiple choice questions in real time (Smith et al., 2011).

3) One-minute papers 
In the end of class an open-ended question is given to students to be answered in one minute by writing the answers on index cards (Rivard \& Straw, 2000).

4) Interactive lecture demonstrations (ILDs)

Students predict the outcome of a classroom demonstration, observe the experiment or demonstration, elaborate the results, and reflect the observed outcome (Sharma et al., 2010).

5) Case studies

Students take inferences and give a detailed description of a scenario based on a true story (Preszler, 2009).

6) Concept mapping

Students make a visual representation (like a flow chart) identifying and indicating the interconnections among various ideas of a specific topic or problem (Yarden et al., 2004).

7) Tutorial worksheets

Based on guided-discovery worksheets students work in small groups to get a chain of logic to fix a problem or a conceptual difficulty, while the instructor guide the groups by giving targeted questions and bring them into discussion (Finkelstein \& Pollock, 2005).

8) Problem-based learning

In groups students learn to cope with complex, multifaceted, and realistic problems, to find necessary background material as needed (Preszler et al., 2007).

9) Just-in-time teaching

Students answer the questions about pre-class reading online, a few hours before class. Answers are classified based on completion and effort, not correctness, and give the instructor's lesson plans (Marrs \& Novak, 2004).

10) Analytical challenge before lecture (also called "invention activities")

Students try to answer questions before finding the answers in class (Schwartz \& Bransford, 1998).

11) Computer simulations and games

By using interactive computer simulations or online games students learn to visualize phenomena, test predictions, receive prompt, targeted feedback to analyze virtual experiments (Harris et al., 2009).

12) Group tests

The same students get a test twice individually and in groups (Klappa, 2009).

13) Problem sets in groups

Students try to fix problem sets in groups and hand in one set of solutions per team (Cortright et al., 2005).

14) Random calling

The students are chosen at random to answer questions from the teacher. The teacher invites student by student at random to share comment on a student's response (Buck, 1997).

15) Writing with peer review

Students evaluate each other's writing using a rubric or criteria provided by the instructor (Pelaez, 2002).

\subsection{Pedagogy}

Pedagogy is etimologically also a Greek root word, peda or paid which is equivalent in meaning with child. It is terminologically defined as the art and science of teaching children (Knowles, 1980 and Conner, 2004). Students with pedagogical orientation have no necessity to know the reason of their learning as they are dependent on their teachers. In other words, in pedagogy the teacher is the centre of teaching, and the teacher with approval as well parental pressures, grades motivate the students to study.

\subsubsection{Pedagogically Oriented Teaching Method (POTM)}

Pedagogy does not belong to teaching method, but tends to go to the level philosophical concepts representing the adult learners' involvement in teaching and learning process. The pedagogical effects in teaching are seen through teaching methods. In other words, there are many teaching methods representing and orienting to pedagogy or pedagogically oriented. Those kinds of teaching methods are as presented as follows:

1) Direct instruction 
The teacher as the centre of teaching provides the academic content to direct the activities of students and maintain a focus on academic achievement (Killen, 1998).

2) Lecture by teacher

Teacher asks students to listen and respond information in classical teaching (Marsh, 2000).

3) Recitation oral questions by teacher answered orally by students

Teacher presents questions and occassional question which students have to answer (Marsh, 2000).

4) Lecture-demonstration by teacher

Teacher gives information and material students observe, listen, and practice (Marsh, 2000).

5) Classwork and homework assignments

(Module 4-B).

6) Construction of vocabulary lists and vocabulary drills

Teacher gets students listen and repeat vocabularies the teacher gives (Marsh, 2000).

7) Memorizing

The students memorize things, even though they do not understand (Module 4-B).

8) Reviewing

Reviewing is given to increase understanding by exposuring semantic network (Module 4-B).

9) Questioning

Teacher provides well-formed questions to students for developing critical thinking skills (Module 4-B and Setianingrum \& Saleh, 2016).

10) Discussion led by teacher

(Module 4-B).

11) Textbook assignment

Assignments from textbooks are given to students as learning material and student worksheet (Rukmini, 2009)

\subsection{Differences between Pedagogy and Andragogy}

Based on Knowles' opinions $(1980,1987)$ on pedagogy and andragogy, the following is head to head comparison of andragogy and pedagogy:

Table 1. Differences between andragogy and pedagogy

\begin{tabular}{|c|c|}
\hline Andragogy & Pedagogy \\
\hline $\begin{array}{l}\text { Learners demand themselves to be the instructor to } \\
\text { have responsibility for decisions about curriculum, } \\
\text { skills acquisition, teaching methodology, and } \\
\text { evaluation of learning. }\end{array}$ & $\begin{array}{l}\text { Learners demand the instructor to have responsibility } \\
\text { for decisions about curriculum, skills acquisition, } \\
\text { teaching methodology, and evaluation of learning. }\end{array}$ \\
\hline It implements a "student-centered" approach & It implements a "teacher-centered" approach \\
\hline $\begin{array}{l}\text { Learners' prior experience significantly affects their } \\
\text { learning process or outcome. }\end{array}$ & $\begin{array}{l}\text { Learners' prior experience does not significantly affect } \\
\text { their learning process or outcome. }\end{array}$ \\
\hline $\begin{array}{l}\text { Learners" "readiness to learn "is encouraged mostly by } \\
\text { internal stimuli, such as an increase in salary or } \\
\text { advancement of position }\end{array}$ & $\begin{array}{l}\text { Learners" "readiness to learn "is encouraged mostly by } \\
\text { external stimuli, such as an increase in salary or } \\
\text { advancement of position }\end{array}$ \\
\hline $\begin{array}{l}\text { Learners explore or experience interest in learning } \\
\text { better than drawn specific educational subjects }\end{array}$ & $\begin{array}{l}\text { Learners are "drawn" to specific educational subjects } \\
\text { rather than exploring or experiencing interest in } \\
\text { learning }\end{array}$ \\
\hline $\begin{array}{l}\text { Learners are motivated by internal negative pressures } \\
\text { from parents, peers, and professional colleagues }\end{array}$ & $\begin{array}{l}\text { Learners are motivated by external negative pressures } \\
\text { from parents, peers, and professional colleagues }\end{array}$ \\
\hline $\begin{array}{l}\text { It represents an alternative set of assumptions about } \\
\text { how adults learn }\end{array}$ & It represents a basic ideology \\
\hline It is "process-oriented" & It is "content-oriented" \\
\hline
\end{tabular}




\subsection{Gender, Language Learning, and Teaching Competency}

The female and male difference in language learning has been a popular issue in language acquisition. So far, the common belief is that females are better language learners than males. Saville-Troike (2005) and also Yonata and Mujiyanto (2017) note that although the beliefs in many western culture states that females tend to be better language learners, it might reflect social construct. Van der Silk et al. (2015) add other factors such as genes and environment that interact in complex ways and in various levels from the individual and societal.

However, some studies indicate that the female and male differences exist and affect language learning. Viriya and Sapsirin (2014) revealed that gender influences language learning style, but not language learning strategies. This means that there is no difference in using language learning strategies between females and males learners.

The study by Zoghi et al. (2013) showed that gender brings impact to EFL learning and it has a signficant effect on the achievement test. They found out females out-perfomed males in the EFL achievement test. This is in line with the study conducted by Saidi and AL-Mahrooqi (2012) yielding that females and males perform differences in language comprehension. In addition, the study revealed that the gender differences in English learning include the differences in language learning strategies and language learning motivation in which females tended to be better than males.

In language teaching competency, male and female are believed to have difference. Kartik, P., \& Ahuja, M. (2016) in their research mentioned that male trainees were concluded to be more competent in implementing of pre-instructional teaching skills compared to their female trainees; male trainees had higher in teaching competency (instructional skills) than female trainees; and male trainees were superior to female trainees regarding with their teaching competency on post-instructional skills.

\section{Method}

This study is quantitative with pre-test and post-test as the instrument. The test is to measure the significant difference of the male and female students' SIP achievement in the form of teaching prctice taught by using AOTM and POTM.

This study took place at Englsih Education Department of Muria Kudus University with 87 students joining SIP classes as the sample. Those 87 students are more dominated by female students than by the male students; 73 female students and 14 male students. The number of students is divided into 2 SIP classes. One SIP class consisting of 48 students (10 males and 38 females) was taught by AOTM, and the other SIP class consisting of 39 students ( 4 males and 35 females) was taught by POTM.

\section{Results}

The female students' SIP achievement taught by using AOTM and POTM does not have any significant difference; while the male students' SIP achievement taught by using AOTM and POTM has significant difference. The detail of data analysis of the two groups of students is as follows:

\subsection{The Female Students' SIP Achievement Taught by Using AOTM and POTM}

The following table contains the N-gain data of the female students' SIP achievement taught by using AOTM and POTM which can be used to prove the possibility of that significant difference:

Table 2. N-Gain of the female students'SIP achievement at EED MKU taught by using AOTM and POTM

\begin{tabular}{lllllllll}
\hline Std & MV/Method & N-Gain & Std & MV/Method & N-Gain & Std & MV/Method & N-Gain \\
\hline 1 & FAOTM & 0.51 & 26 & FAOTM & 0.4 & 51 & FPOTM & 0.56 \\
2 & FAOTM & 0.45 & 27 & FAOTM & 0.59 & 52 & FPOTM & 0.74 \\
3 & FAOTM & 0.56 & 28 & FAOTM & 0.65 & 53 & FPOTM & 0.67 \\
4 & FAOTM & 0.45 & 29 & FAOTM & 0.58 & 54 & FPOTM & 0.67 \\
5 & FAOTM & 0.58 & 30 & FAOTM & 0.41 & 55 & FPOTM & 0.49 \\
6 & FAOTM & 0.47 & 31 & FAOTM & 0.49 & 56 & FPOTM & 0.63 \\
7 & FAOTM & 0.45 & 32 & FAOTM & 0.81 & 57 & FPOTM & 0.28 \\
8 & FAOTM & 0.44 & 33 & FAOTM & 0.45 & 58 & FPOTM & 0.19 \\
9 & FAOTM & 0.46 & 34 & FAOTM & 0.57 & 59 & FPOTM & 0.52 \\
10 & FAOTM & 0.55 & 35 & FAOTM & 0.46 & 60 & FPOTM & 0.51
\end{tabular}




$\begin{array}{lllllllll}11 & \text { FAOTM } & 0.54 & 36 & \text { FAOTM } & 0.52 & 61 & \text { FPOTM } & 0.34 \\ 12 & \text { FAOTM } & 0.55 & 37 & \text { FAOTM } & 0.51 & 62 & \text { FPOTM } & 0.06 \\ 13 & \text { FAOTM } & 0.42 & 38 & \text { FAOTM } & 0.21 & 63 & \text { FPOTM } & 0.65 \\ 14 & \text { FAOTM } & 0.47 & 39 & \text { FPOTM } & 0.31 & 64 & \text { FPOTM } & 0.41 \\ 15 & \text { FAOTM } & 0.4 & 40 & \text { FPOTM } & 0.83 & 65 & \text { FPOTM } & 0.42 \\ 16 & \text { FAOTM } & 0.6 & 41 & \text { FPOTM } & 0.42 & 66 & \text { FPOTM } & 0.78 \\ 17 & \text { FAOTM } & 0.88 & 42 & \text { FPOTM } & 0.35 & 67 & \text { FPOTM } & 0.75 \\ 18 & \text { FAOTM } & 0.51 & 43 & \text { FPOTM } & -0.1 & 68 & \text { FPOTM } & 0.44 \\ 19 & \text { FAOTM } & 0.53 & 44 & \text { FPOTM } & 0.65 & 69 & \text { FPOTM } & 0.51 \\ 20 & \text { FAOTM } & 0.62 & 45 & \text { FPOTM } & 0.58 & 70 & \text { FPOTM } & 0.61 \\ 21 & \text { FAOTM } & 0.31 & 46 & \text { FPOTM } & 0.34 & 71 & \text { FPOTM } & 0.54 \\ 22 & \text { FAOTM } & 0.58 & 47 & \text { FPOTM } & 0.66 & 72 & \text { FPOTM } & 0.35 \\ 23 & \text { FAOTM } & 0.61 & 48 & \text { FPOTM } & 0.7 & 73 & \text { FPOTM } & 0.8 \\ 24 & \text { FAOTM } & 0.61 & 49 & \text { FPOTM } & 0.59 & & & \\ 25 & \text { FAOTM } & 0.47 & 50 & \text { FPOTM } & 0.49 & & & \end{array}$

Note: Std (student); MV (moderator variable); F (female).

SPSS program analyzes the N-gain data in Table 2 to check whether the students' SIP achievement taught by using AOTM and POTM has a significant difference or not. The SPSS output in Table 3 below views the result of the analysis:

Table 3. Test statistics ${ }^{\mathrm{a}}$

\begin{tabular}{ll}
\hline & Class \\
\hline Mann-Whitney U & 636.000 \\
Wilcoxon W & $1.377 \mathrm{E} 3$ \\
$\mathrm{Z}$ & -.320 \\
Asymp. Sig. (2-tailed) & .749 \\
\hline
\end{tabular}

a. Grouping Variable: Code.

Table 2 shows that the female students' SIP achievement taught by using AOTM and POTM has no significant difference as the level of significance of the SIP achievement of both groups of students reaches 0.749 which is higher than 0.05 .

\subsection{The Male Students'SIP Achievement Taught by Using AOTM and POTM}

The following table contains the N-gain data of the male students' SIP achievement taught by using AOTM and POTM which can be used to prove the possibility of that significant difference:

Table 4. N-Gain of the male students'SIP achievement at EED MKU taught by using AOTM and POTM

\begin{tabular}{lllllllll}
\hline Std & MV/Method & N-Gain & Std & MV/Method & N-Gain & Std & MV/Method & N-Gain \\
\hline 1 & MAOTM & 0.71 & 6 & MAOTM & 0.51 & 11 & MPOTM & 0.27 \\
2 & MAOTM & 0.62 & 7 & MAOTM & 0.61 & 12 & MPOTM & 0.38 \\
3 & MAOTM & 0.46 & 8 & MAOTM & 0.59 & 13 & MPOTM & 0.30 \\
4 & MAOTM & 0.45 & 9 & MAOTM & 0.63 & 14 & MPOTM & 0.48 \\
5 & MAOTM & 0.48 & 10 & MAOTM & 0.54 & & & \\
\hline
\end{tabular}

Note: Std (student); MV (moderator variable); M (male). 
SPSS program analyzes the N-gain data in Table 4 to see whether the students' SIP achievement taught by using AOTM and POTM has a significant difference or not. The SPSS analysis in Table 5 below views the output of the analysis:

Table 5. Test statistics ${ }^{\mathrm{a}}$

\begin{tabular}{ll}
\hline & Class \\
\hline Mann-Whitney U & 2.500 \\
Wilcoxon W & 12.500 \\
$\mathrm{Z}$ & 2.478 \\
Asymp. Sig. (2-tailed) & .013 \\
Exact Sig. [2*(1-tailed Sig.)] & .008 \\
\hline
\end{tabular}

a. Grouping Variable: Code.

b. Grouping Variable: Code.

Table 5 displays that the male students' SIP achievement taught by using AOTM and POTM has a significant difference as the level of significance of the SIP achievement of both groups of students reaches 0.013 which is lower than 0.05 .

\section{Discussion}

The result of this study showed that male students' SIP achievement taught by using AOTM and POTM has a significant difference as the level of significance of the SIP achievement of both groups of students reaches 0.013 which is lower than 0.05 ; while the female students' SIP achievement taught by using AOTM and POTM has no significant difference as the level of significance of the SIP achievement of both groups of students reaches 0.749 which is higher than 0.05 . In other words, AOTM is more effective to be given to the male students than to the female students.

Speaking for Instructional Purposes (SIP) is a course at EED MKU which trains the students to study things needed in teaching classes, and to conduct teaching practice. Those things are how to prepare teaching, how to use and develop instructional skillls of teaching in teaching time, and how to make a sustainable follow up after teaching. This course is to prepare students to have early experience of teaching before they also have more real teaching practices in Microteaching and Teaching Internship courses. That AOTM is implemented in SIP class means the teaching methods oriented to the teaching and learning for adult learners, such as discussion, case studies, and problem based learning are done. The students of SIP class, who are really adult learners, are demanded to learn actively, autonomously, and creatively. Based on the data analysis, AOTM is more effective to be given to male students. This might be in accordance with that naturally males are physically better than male in particular related with conducting physical activities which are more demanded in teaching practice.

Despite the theory revealing that the common belief says that females are better than males in learning language (Saville-Troike, 2005; Yonata \& Mujiyanto, 2017) in particular with their learning styles; male students in this research are better than the female students to implement AOTM as their method orientation in learning SIP. This might be because learning method orientation is closer to learning strategy than to learning style as stated by Viriya and Sapsirin (2014).

Teaching practice does not only need good language mastery but also creativity in preparing the teaching and also using the teaching instructional skills. Males generally have higher physical speed and endurance. In preparing teaching, many physical activities, such as preparing teaching media, setting good classroom circumstance, need to be done. Male students also commonly have stronger voice that enables them to deliver classroom language combined with verbal, non verbal and mixed reinforcements optimumly. Besides, in combining teaching instructional skills, classroom language and classroom management, males could utilize their strenght as well as their higher strictness and bravery in leading and directing the students in classroom. These all might influence the different teaching preparation and teaching practice of males and females. This is in line with what Kartik and Ahuja (2016) found in their research and also with what is found in this study that in fact male students at EED MKU are more appropriate to be taught by using AOTM to improve their teaching achievement in SIP classes.

AOTM compared to POTM both as teaching orientation method was more effective to be given to adult learners 
including to the students of EED MKU particulary in SIP classes in which they learn how to teach EFL well. More specifically, AOTM is more effective to be given to male adult students than to the female adult students in SIP classes despite the belief said that females generally have better achievement in language learning. The fact said that achievement of language learning was not necessarily in line with achievement of teaching, as not only achievement of language learning but also creativity in preparing the teaching and also using the teaching instructional skills which influenced students' achievement of teaching.

\section{References}

Anderson, W. L., Mitchell, S. M., \& Osgood, M. P. (2005). Comparison of Student Performance in Cooperative Learning and Traditional Lecture-Based Biochemistry Classes. Biochemistry and Molecular Biology Education, 33(6), 387-93. https://doi.org/10.1002/bmb.2005.49403306387

Buck, H. J. (1997). Maximizing Student Learning with the Use of Random Oral Questioning in the College Classroom. Florida Journal of Educational Research, 37(1). Retrieved from http://feraonline.org/fjer/archive/1997/1997_Buck.htm.

Choy, S. C., \& Delahaye, B. (2002, March). Andragogy in Vocational Education and Training: Learners' perspective. Paper presented at the 5th Annual Conference of the Australian VET Research Association (AVETRA), Melbourne, Australia.

Christian, A. C. (1983). A Comparative Study of the Andragogical-Pedagogical Orientation of Military and Civilian Personnel. Doctoral dissertation. Oklahoma State University. Retrieved from https://shareok.org/bitstream/handle/11244/20245/Thesis-1982D-C555c.pdf?sequence=1\&isAllowed=y

Conner, M. L. (2004). Andragogy and Pedagogy. Retrieved from $\mathrm{http} / / /$ agelesslearner.com/intros/andragogy.html

Davenport, J., \& Davenport, J. H. (1985). Knowles or Lindeman: Would the Real Father of American Andragogy Please Stand Up?. Lifelong Learning, 9 (3), 4-5.

Deveci, T. (2007). Androgogical and Pedagogical Orientations of Adult Learners Learning English as a Foreign Language. Journal of New Horizons in Adult Education and Human Resource Development, 21(3/4), 16-28. https://doi.org/10.1002/nha3.10287

Finkelstein, N. D., \& S. J. Pollock. (2005). Replicating and Understanding Successful Innovations: Implementing Tutorials in Introductory Physics. Physics Education Research, 1(1), 1-13. https://doi.org/10.1103/PhysRevSTPER.1.010101

Harris, M. A., Peck, R. F., Colton, S., Morris, J., Neto, E. C., \& Kallio, J. (2009). A Combination of Handheld Models and Computer Imaging Programs Helps Students Answer Oral Questions about Mole Cular Structure and Function: A Controlled Investigation of Student Learning. CBE-Life Sciences Education, 8(1), 29-43. https://doi.org/10.1187/cbe.08-07-0039

Henry, G. W. (2009). An Historical Analysis of the Development of Thinking in the Principal Writings of Malcolm Knowles. (Doctoral Dissertation). School of Learning and Professional Studies, Faculty of Education, Queensland University of Technology.

Kartik, P., \& Ahuja, M. (2016). Comparative Study of Teaching Competency of Male and Female Trainees of Govt and Self Financed Colleges. IRA-International Journal of Education \& Multidisciplinary Studies, 4(2), 278-288. https://doi.org/10.21013/jems.v4.n2.p6

Killen, R. (1998). Effective Teaching Strategies (2nd ed.) Australia: Social Science Press.

Klappa, P. (2009). Promoting Active Learning through "Pub Quizzes"- a Case Study at the University of Kent. Bioscience Education, 14(1), 1-6. https://doi.org/10.3108/beej.14.c2

Knowles, M. (1980). The Modern Practice of Adult Education: from Pedagogy to Andragogy. New York: Cambridge Books.

Marrs, K. A., \& Novak, G. M. (2004). Just-in-Time Teaching in Biology: Creating an Active Learner Classroom Using the Internet. Cell Biology Education, 3(1), 49-61. https://doi.org/10.1187/cbe.03-11-0022

Marsh, C. (2000). Handbook for Beginning Teachers (2nd ed). Australia: Pearson Education.

Pelaez, N. J. (2002). Problem-Based Writing with Peer Review Improves Academic Performance in Physiology. Advances in Physiology Education, 26(3), 174-184. https://doi.org/10.1152/advan.00041.2001

Preszler, R. W., Dawe, A., \& Shuster, C. B. (2007). Assessment of the Effects of Student Response Systems on 
Student Learning and Attitudes over a Broad Range of Biology Courses. CBE—Life Sciences Education, 6(1), 29-41. https://doi.org/10.1187/cbe.06-09-0190

Rivard, L. P., \& Straw, S. B. (2000). The effect of talk and writing on learning science: An exploratory study. Science Education, 566-593. https://doi.org/10.1002/1098-237X(200009)84:5\%3C566::AID-SCE2\%3E3.0.CO;2-U

Rukmini, D. (2009). Model Written Texts in the Recommended Senior High School English Textbooks. TEFLIN Journal, 20(2), 180-193.

Saidi, A. A., \& Rahma, Al-Mahrooqi. (2012). The Influence of Gender on Omani College Students' English Language Learning Strateges, Comprehensiion, and Motivation. International Journal of Applied Linguistics and English Literature, 1(4), 230-244. https://doi.org/10.7575/ijalel.v.1n.4p.230

Saville-Troike, M. (2015). Introducing Second Language Acquisition. Cambridge: Cambridge University Press.

Schwartz, D. L., \& Bransford, J. D. (1998). A Time for Telling. Cognition \& Instruction, 16(4), 475-522. https://doi.org/10.1207/s1532690xci1604_4

Sealana, R. K. (2014). Examining the Efficacy of Adult Learning of Government-Mandated Content Using Andragogical Delivery Methods versus Traditional Pedagogical Delivery Methods. San Fransisco: University of San Francisco.

Setianingrum, D., \& Saleh, M. (2016). Classroom Interaction Patterns in Higher Education. English Education Journal, 6(2), 10-16.

Sharma, M., Johnston, I. D., Johnston, H., Varvell, K., Robertson, G., Hopkins, A., Stewart, C., Cooper, I., \& Thornton, R. (2010). Use of interactive lecture demonstrations: A ten year study. Physics Education Research, 6(2), 1-9. https://doi.org/10.1103/PhysRevSTPER.6.020119

Smith, M. K., Wood, W. B., Krauter, K., \&Knight, J. K. (2011). Combining Peer Discussion with Instructor Explanation Increases Student Learning from In-Class Concept Questions. CBE Life Sciences Education, 10(1), 55-63. https://doi.org/10.1187/cbe.10-08-0101

Van, der Silk, FWP, et al. (2015). The Gender Gap in Second Language Acquisition: Gender Differences in the Acquisition of Dutch among Immigrants from 88 Countries with 49 Mother Tounges, PLOS One, 10(11), $1-22$.

Viriya, C., \& Sutthirak, S. (2014). Gender Differences in Language learning Style and language learning Strategies. Indonesian Journal of Applied Linguistics, 3(2), 77-88. https://doi.org/10.17509/ijal.v3i2.270

Yarden, H., Marbach-ad, G., \& Gershoni, J. M. (2004). Using the Concept Map Technique in Teaching Introductory Cell Biology to College Freshmen. Bioscene: Journal of College Biology Teaching, 30(1), 3-13.

Yonata, F., \& Mujiyanto, Y. (2017). The Representation of Gender in English Textbooks in Indonesia. Language Circle: Journal of Language and Literature, 12(1), 91-102.

Zoghi, M. et al. (2013). The Effect of Gender on Language Learning. Journal of Novel Applied Sciences, 2(S4), 1124-1128.

\section{Copyrights}

Copyright for this article is retained by the author(s), with first publication rights granted to the journal.

This is an open-access article distributed under the terms and conditions of the Creative Commons Attribution license (http://creativecommons.org/licenses/by/4.0/). 